\title{
Heterologous microsatellite-based genetic diversity in blue mussel (Mytilus chilensis) and differentiation among localities in southern Chile
}

\author{
María Angélica Larraín ${ }^{1}$, Nelson F. Díaz ${ }^{2}$, Carmen Lamas ${ }^{2}$, Carla Uribe ${ }^{2}$ \\ Felipe Jilberto $^{2}$ \& Cristián Araneda ${ }^{2}$ \\ ${ }^{1}$ Departamento de Ciencia de los Alimentos y Tecnología Química \\ Facultad de Ciencias Químicas y Farmacéuticas, Universidad de Chile \\ Sergio Livingstone 1007 Independencia, Santiago, Chile \\ ${ }^{2}$ Departamento de Producción Animal, Facultad de Ciencias Agronómicas, Universidad de Chile \\ Corresponding author: María Angélica Larraín (mlarrain@uchile.cl)
}

\begin{abstract}
Mussels (Mytilus spp.) are one of the most cultivated and commercialized bivalves in southern Chile; culture is currently supplied almost entirely from wild-caught seed obtained from relatively few collection centers. The genetic diversity and differentiation of the blue mussel in southern Chile was investigated by sampling six locations: one natural bank and five seed collection centers. Nine polymorphic microsatellite (SSR) loci were genotyped (Mgul, Mgu3, MT203, MT282, Mg15, Mg56, Med737, MIT02 and MGE005). We found 75 different alleles, six of which were private alleles. Of the analyzed loci, 45 of 54 tests performed deviated from Hardy-Weinberg equilibrium after sequential Bonferroni correction $(P<0.05)$, revealing significant heterozygote deficiencies. The polymorphic information content (PIC) ranged from 0.322 (MGE005) to 0.893 (Mgul). Despite the long distance between some sampling sites (up to $1360 \mathrm{~km}$ ), genetic differentiation among the sites was low $\left(F_{S T}=0.043, P<0.0001\right)$. The Bayesian cluster analysis (STRUCTURE) indicated two probable clusters, while the non-parametric cluster analysis (AWclust) identified two to four clusters. Both analyses showed a high level of admixture within clusters. Our results indicate that blue mussels in southern Chile show lower genetic diversity than in other countries, low inbreeding levels, and limited genetic differentiation among locations.
\end{abstract}

Keywords: Mytilus, mussels, genetic diversity, genetic differentiation, microsatellites, southern Chile.

\section{Diversidad genética del mejillón (Mytilus chilensis) y diferenciación entre localidades del sur de Chile usando marcadores microsatélites heterólogos}

\begin{abstract}
RESUMEN. Los mejillones (Mytilus spp.) constituyen unos de los bivalvos más cultivados y comercializados en el sur de Chile. Su cultivo está actualmente abastecido completamente con semillas obtenidas desde el medio natural, de relativamente pocos centros de captación. La diversidad y diferenciación genética de los mejillones en el sur de Chile fue investigada muestreando seis lugares, un banco natural y cinco centros de captación de semilla. Se genotiparon nueve loci microsatélite (SSR) polimórficos (Mgu1, Mgu3, MT203, MT282, Mg15, Mg56, Med737, MIT02 y MGE005). Se encontraron 75 alelos diferentes, seis de ellos fueron alelos privados. En los loci analizados, 45 de los 54 test realizados mostraron desviación significativa $(P<0,05)$ del equilibrio de Hardy-Weinberg después de la corrección secuencial de Bonferroni, revelando un significativo déficit de heterocigotos. El contenido de información polimórfica (PIC) varió entre 0,322 (MGE005) y 0,893 (Mgul). A pesar de la gran distancia entre algunos sitios de muestreo (hasta $1.360 \mathrm{~km}$ ), la diferenciación genética entre ellos fue baja $\left(F_{S T}=0,043 ; P=0,00\right)$. El análisis Bayesiano de agrupamiento (STRUCTURE) indicó que la estructura poblacional más probable consiste en dos grupos, en tanto el análisis de agrupamiento no paramétrico (AWclust) identificó entre dos y cuatro grupos, ambos análisis mostraron un alto nivel de mezcla dentro de los grupos. Estos resultados indican que los mejillones del sur presentan menor diversidad genética que en otros países, baja endogamia y diferenciación genética entre localidades.
\end{abstract}

Palabras clave: Mytilus, mejillones, diversidad genética, diferenciación genética, microsatélites, sur de Chile.

Corresponding editor: Cristian Aldea 
Mussels from the genus Mytilus, widely used for human consumption, are among the most cultivated and marketed bivalves. Chilean mussel culture yielded $10.8 \%$ of the world's Mytilidae production in 2012 (FAO, 2015). The distribution range for this species extends along the Chilean coast from Arauco $\left(35^{\circ} \mathrm{S}\right)$ to Cape Horn $\left(55^{\circ} S\right.$ ) (Hernández \& González, 1976), but nearly $100 \%$ of production comes from Chiloé Island and the mainland in the $41-44^{\circ} \mathrm{S}$ region (SERNAPESCA, 2015).

The name Mytilus chilensis (Hupé, 1854) was initially given to the native Chilean blue mussel, but the names M. edulis chilensis (Toro, 1998) and $M$. galloprovincialis chilensis (Cárcamo et al., 2005) were later proposed. Also, the species M. galloprovincialis described in the coasts of Chile was found to be distinct from the endemic Mytilus according to various molecular evidence (Tarifeño et al., 2005; Toro et al., 2005; Astorga \& Toro, 2010), other authors (Westfall \& Gardner, 2010) reported that the blue mussel now found in Chile is a mix of native Southern-hemisphere and introduced Northern-hemisphere M. galloprovincialis and $M$. edulis and their respective hybrids. Borsa et al. (2012) proposed the taxonomic status $M$. galloprovincialis planulatus and M. edulis platensis for these species, respectively. Since 2013, the WoRMS no longer recognizes the name Mytilus chilensis Hupé, 1854 (Boxshall et al., 2014) for the native Chilean smooth-shelled mussel, replacing it with the name Mytilus edulis platensis d'Orbigny, 1842 (Borsa et al., 2012). However, the name Mytilus chilensis is still used commercially, in statistics, in certifications, and on food product labels (GAA, 2013; FAO, 2015), and also by authors (Gazeau et al., 2013; Riisgard et al., 2013; Astorga, 2014; Larraín et al., 2014; Oyarzún et al., 2014; Ouagajjou \& Presa, 2015). Moreover, there is evidence suggesting that $M$. chilensis is a valid, distinct species within the genus based on the strong genetic and reproductive differences versus the native Chilean mussel, M. galloprovincialis (Mediterranean and Atlantic populations) and M. edulis found when these taxa were evaluated with a 54-SNP panel developed by Zbawicka et al. (2014) as marker for Mytilus taxa (R. Wenne pers. comm.), with microsatellite markers (Ouagajjou et al., 2011), mitochondrial cytochrome oxidase I gene (COI) (Seguel, 2011), and sperm morphology (Oyarzún et al., 2014). Therefore, we use the name $M$. chilensis for the native and predominant blue mussel species that inhabits the Chilean coast.

The long larval phase of the Mytilus lifecycle extends its dispersal capacity to large geographic areas, increasing gene flow, preventing differentiation among populations, and preserving high levels of diversity within populations (Toro et al., 2006). Currently, aquaculture farms are supplied solely with seed collected from the wild in the area of the Reloncaví estuary and Chiloé Island (Bagnara \& Maltraín, 2008). In 2012-2013 a significant decrease in seed supply from the collection centers was reported for the zone.

Understanding the genetic diversity and differentiation of economically-important species is fundamental for supporting management and conservation programs, enhancing production, and exploring the possibility of developing DNA-based traceability systems using allocation algorithms. In Chile, studies of Mytilus genetic diversity and differentiation have been performed using RAPDs and allozyme markers (Toro et al., 2004, 2006), producing no evidence of discrete stocks, with the possible exception of a Magallanes population (Punta Arenas 53 ${ }^{\circ} \mathrm{S}$ ). Microsatellite markers are an important tool used to assess genetic diversity levels and population structures in marine species (Liu \& Cordes, 2004); these markers have been applied to the Mytilidae family for species such as Perumytilus purpuratus (Perez et al., 2008; Briones et al., 2013), M. galloprovincialis (Diz \& Presa, 2008, 2009), M. edulis, and M. trossulus (Kijewski et al., 2009; Shields et al., 2010). In Chilean blue mussels, SSR have been used by Vidal et al. (2009) and Ouagajiou et al. (2011) in cross-species amplification and allelic variation assessment, respectively, on a limited number of individuals from a single location, but to date there are no published studies of genetic diversity or differentiation among locations using this tool.

The current study aims to investigate the genetic diversity and differentiation of Mytilus chilensis in southern Chile using nine heterologous SSR loci. This survey complements previous population studies conducted in the region based on allozyme and RAPDs analysis, with more informative SSR markers.

Mussel samples ( $\mathrm{n}=50$ by location) were collected in southern Chile from three zones: 1) Reloncaví (Quillaipe: 1-QI, Pichicolo: 1-PI, Caleta La Arena: 1LA, and Canutillar: 1-CN), 2) Chiloé (Canal ColditaPiedra Blanca: 2-CB), and 3) Magallanes (Isla Peel: 3IP). In zones 1 and 2, where mussel aquaculture activities are carried out, we sampled seed collection centers, and in zone 3, the source was a natural bank. Detailed information about sampling, DNA extraction, genus, and species identification can be found in Larraín et al., (2012, 2014). Only M. chilensis individuals, identified according to designation at the RFLP-PCR Me 15-16 Aci I marker (Inoue et al., 1995; Santaclara et al., 2006), were used for microsatellite analysis. Nine SSR loci were genotyped. The repeat motifs obtained from GenBank sequences by accession number were: mononucleotide (Mg15) (Cruz et al., 
2005), perfect dinucleotide (Mgu3, MT203, MT282, MIT02, MGE005) (Presa et al., 2002; Gardeström et al., 2007; Yu \& Li, 2007; Vidal et al., 2009), compound dinucleotide (Mgul, Med737) (Presa et al., 2002; Lallias et al., 2009), and complex (Mg56) (Cruz et al., 2005). Detailed information about primers and PCR conditions used to amplify eight of the motifs (Mgul, Mgu3, MT203, MT282, Mg15, Mg56, Med737 and MIT02) are described in Larraín et al. (2014). The other locus used in this work was MGE005 (Yu \& Li, 2007). For this last locus, primers (F: 5'-AGACCAAGGTA TTGCAACCATGTG-3 and R: 5'-TCGAAAGCATG GTACCTGGTCA-3') were obtained using AmplifX (http://crn2m.univ-mrs.fr/recherche/brue/jullien-nicolas/ programmation/amplifx) and the Primer Blast NCBI utility (http://www.ncbi.nlm.nih.gov/tools/ primer-blast/). The primers were commercially synthesized by Integrated DNA technologies Inc. (IDT) (Singapore). The PCR thermal profile to amplify the MGE005 locus was $95^{\circ} \mathrm{C}$ for $5 \mathrm{~min}$, followed by 35 cycles at $95^{\circ} \mathrm{C}(1$ $\mathrm{min}), 67^{\circ} \mathrm{C}(30 \mathrm{~s}), 72^{\circ} \mathrm{C}(50 \mathrm{~s})$, and a final 10 -min extension step at $72^{\circ} \mathrm{C}$. PCR amplification was carried out in a $15-\mu \mathrm{L}$ reaction mixture containing $1.5 \mu \mathrm{L}$ of 10x PCR buffer, $1.5 \mathrm{mM} \mathrm{MgCl} 2,100 \mu \mathrm{M}$ each of dNTP, $0.3 \mu \mathrm{M}$ of each primer, $0.5 \mathrm{U}$ Taq DNA Polymerase (RBC Bioscience ${ }^{\circledR}$ ), and 40 ng of DNA. A negative control with template DNA replaced by water was performed for each set of amplifications. To evaluate amplification, PCR products were visualized on an agarose gel (1.8\%) in TBE buffer with $10 \mathrm{mg} \mathrm{mL}^{-1}$ of ethidium bromide under ultraviolet light. For genotyping, polyacrylamide gels $(6 \%)$ with silver staining were used to resolve alleles (Larraín, 2012); for every gel, the size of amplified fragments was estimated from a 10-bp DNA ladder (Invitrogen ${ }^{\circledR}$ ) or HyperLadder V (Bioline ${ }^{\circledR}$ ).

The Excel add-in MS tools (Park, 2001) and CONVERT software (Glaubitz, 2004) were used to reformat diploid genotypic data. MICRO-CHECKER (Van Oosterhout et al., 2004) was used to test for the presence of null alleles, stuttering, and large allele dropout. Genetic diversity was determined by the observed number of alleles per locus $(\mathrm{Na})$, observed $\mathrm{Ho}$ ) and expected $\mathrm{(He}$ ) heterozygosities, polymorphic information content $(P I C)$, and the presence of private alleles, using MS tools (Park, 2001). Genepop 4.0.10 (Raymond \& Rousset, 1995; Rousset, 2008) was used to test genotypic linkage disequilibria $(L D)$ between each pair of loci, to evaluate genotypic distributions for conformation to Hardy-Weinberg equilibrium (HWE), and to estimate Wright's fixation indices $\left(F_{I S}, F_{S T}\right.$, and $\left.F_{I T}\right)$ according to Weir \& Cockerham (1984). Exact $P$ values were estimated by the Markov chain method (Guo \& Thompson, 1992), using default software conditions. Sequential Bonferroni correction was used for multiple tests (Holm, 1979; Rice, 1989). The relatedness index $r_{x y}$ (Queller \& Goodnight, 1989) for each pair of individuals was obtained using Identix software (Belkhir et al., 2002). Genetic differentiation among locations was determined with Genetix 4.05 (Belkhir et al., 1996) to estimate pairwise $F_{S T}$ and its statistical significance and to perform a three-dimensional factorial correspondence analysis (3D-FCA). The Mantel test (Mantel, 1967) was performed to test an isolation-by-distance model of genetic differentiation. Correlation coefficient $(r)$ calculations were performed with Genetix 4.05, and the significance of the associations was tested with 10,000 iterations. We compared the genetic distance matrices $\left(F_{S T} /\left(1-F_{S T}\right)\right)$ with the logarithm of the minimal geographic distance estimated by the coastline (Abbott et al., 2013), as recommended for a two-dimensional habitat (latitude and longitude) (Rousset, 2008). The genetic structure was investigated with parametric-with -STRUCTURE 2.3.4 (Pritchard et al., 2000)- and non-parametric AWclust (Gao \& Stramer, 2008)- frameworks. The Bayesian approach (STRUCTURE) was performed using the standard burn-in period length $(50,000)$ and number of MCMC reps after burn-in $(100,000)$ (Falush et al., 2007), achieving convergence with our data. Ten repeated runs were performed, selecting $\mathrm{K}=6$, the admixture ancestry, and the correlated allele frequency models. The number of clusters $(\mathrm{K})$ that best fit the data was inferred using Delta $\mathrm{K}$ values as described by Evanno et al. (2005) and calculated using the STRUCTURE Harvester webpage (Earl \& von Holdt, 2012). The R package AWclust -allele sharing distance and Ward's minimum variance hierarchical clustering(Gao \& Starmer, 2008) was used, converting the multiallelic SSR data according to Wei et al. (2013).

Null alleles were present in all locations for loci Mgul, Mgu3, MT203, Mg15, Mg56, and MITO2 and in some locations for loci MT282 and Med737 but not detected in any location for locus MGE005. The frequency of non-amplifying individuals (putative null allele homozygotes) was less than 5\% for all loci, and thus all were used in further analysis (Dąbrowski et al., 2014).

All loci showed common allele distributions among sites. Six private alleles, i.e., alleles unique to a single site, were found at low frequency (0.01-0.02) in the seed collection centers Pichicolo (1-PI) and Caleta La Arena (1-LA) at locus $M g u 3$, Canal Coldita-Piedra Blanca (2-CB) at locus $M g 56$, Quillaipe (1-QI) at locus Med737, and Quillaipe (1-QI) and Canutillar (1-CN) at locus MGE005 (Annex 1). A total of 75 alleles were detected at the nine loci among the analyzed individuals (Table 1). All loci were polymorphic in all locations as the frequency of the most common allele did not 
Table 1. Global genetic diversity estimators by locus in samples $(\mathrm{n}=300)$ of blue mussel (Mytilus chilensis) in southern Chile using nine SSR loci. Na: number of alleles, Ho: the observed heterozygosity, He: the expected heterozygosity, PIC: polymorphic information content and the fixation indices $F_{I S}, F_{S T}, F_{I T}$, according to Weir \& Cockerham (1984).

\begin{tabular}{lrcccccr}
\hline Locus & $\mathrm{Na}$ & $\mathrm{Ho}$ & $\mathrm{He}$ & $\mathrm{PIC}$ & $F_{I S}$ & $F_{S T}$ & $F_{I T}$ \\
\hline Mgul & 15 & 0.407 & 0.903 & 0.893 & 0.542 & 0.021 & 0.551 \\
Mgu3 & 6 & 0.097 & 0.610 & 0.540 & 0.802 & 0.227 & 0.847 \\
MT203 & 10 & 0.453 & 0.782 & 0.757 & 0.413 & 0.015 & 0.422 \\
MT282 & 4 & 0.543 & 0.616 & 0.543 & 0.111 & 0.010 & 0.119 \\
Mg15 & 4 & 0.416 & 0.694 & 0.630 & 0.395 & 0.012 & 0.403 \\
Mg56 & 11 & 0.470 & 0.760 & 0.725 & 0.369 & 0.026 & 0.385 \\
Med737 & 10 & 0.483 & 0.756 & 0.721 & 0.319 & 0.073 & 0.369 \\
MIT02 & 5 & 0.365 & 0.617 & 0.544 & 0.411 & 0.000 & 0.409 \\
MGE005 & 10 & 0.320 & 0.330 & 0.322 & 0.032 & 0.000 & 0.031 \\
Global & 75 & 0.395 & 0.674 & 0.631 & 0.393 & 0.043 & 0.419 \\
\hline
\end{tabular}

exceed 0.95 ; average number of alleles per locus was $8.3 \pm 3.8$, ranging from four for $M T 282$ and $M g 15$ in all locations to 15 for $M g u l$ in Quillaipe (1-QI) and Pichicolo (1-PI) (Annex 2). PIC values ranged from 0.322 at locus MGE005 to 0.893 at locus Mgul (Table 1 ). With the exception of locus MGE005, which was moderately informative, all other loci were highly informative (PIC > 0.5) (He et al., 2012). Ho ranged from 0.097 (Mgu3) to 0.543 (MT282), while $\mathrm{He}$ values ranged from 0.330 (MGE005) to 0.903 (Mgul) (Table 1). Significant deviations from HWE were observed in 45 of the 54 tests ( 9 loci $\times 6$ locations), performed after correction for multiple testing (Holm, 1979; Rice, 1989). Significant deviations corresponded to positive $F_{I S}$ values observed in various loci, indicating heterozygote deficiencies. Tests for linkage disequilibrium $(L D)$ showed no significant deviations for any of the 216 tests performed (36 locus combinations $\times 6$ locations) after sequential Bonferroni correction for multiple tests (Holm, 1979; Rice, 1989).

Although average relatedness $\left(r_{\mathrm{xy}}\right)$ between pairs of individuals from the same site was significantly higher than between pairs of randomly-mixed individuals from different locations, at $-0.019 \pm 0.0013$ and -0.137 \pm 0.0009 , respectively $(P<0.0001)$, neither value was significantly different from zero.

Pairwise $F_{S T}$ values among all six locations indicate (Table 2) that the highest $F_{S T}(0.1112)$ value was between Canal Coldita-Piedra Blanca (2-CB) and Caleta La Arena (1-LA). Fourteen of the 15 tests $(P<$ $0.05)$ showed significant pairwise $F_{S T}$ values after correction for multiple comparisons (Holm, 1979; Rice, 1989). The global $F_{S T}$ value indicates that $4.3 \%$ of the total allele frequency variance lies among sample sites and is highly significant $(P<0.0001)$, while $95.7 \%$ is explained by the variation within sites. The first three components of the 3D-FCA (Fig. 1) account for $81.78 \%$ of the total variation in multilocus genotypes, $43.38 \%$ of which is explained by Axis 1, which separates Caleta La Arena (1-LA) from the other five sites, $22.18 \%$ by Axis 2, which separates Quillaipe (1QI) and Canal Coldita-Piedra Blanca (2-CB) from the other sites, and $16.22 \%$ by Axis 3, which separates the most southern sample (3-IP). The Mantel test showed no significant correlation $(r=-0.0130, P=0.3610)$ between genetic and geographic distance.

Bayesian clustering analysis indicated that $\mathrm{K}=2$ (Fig. 2a) is the most likely value for inferred Mytilus chilensis clusters in the zone. The analysis showed that individuals from 1-LA were grouped together in cluster II and 2-CB in cluster I, with high average proportions of membership at 0.966 and 0.824 , respectively (Table $3 a)$, coinciding with the separation of these sites as shown by 3D-FCA. All other sites appeared to be highly admixed with individuals sharing membership between both clusters. The gap analysis from AWclust showed 3 clusters, by a narrow margin with widely overlapping error bars for $\mathrm{K}=2$ and 4 (Fig. 2b). As in the STRUCTURE analysis, a large proportion (0.72) of 1-LA individuals were grouped into a single cluster (cluster III) (Table 3b).

Microsatellites are one of the most informative genetic markers at the intra-specific level, used extensively to study marine species. However, in Mytilus, a relatively low number of SSR markers have been described compared with other aquaculture species such as salmon or trout, which have more than 2000 mapped SSR markers (Guyomard et al., 2012).

Genetic diversity is essential because it allows for population and species survival and adaptation to changing environmental conditions (Mohanty et al., 2014). The total of 75 alleles detected after genotyping 
Table 2. Pairwise $F_{S T}$ values between the blue mussel's (Mytilus chilensis) locations in southern Chile. Zone and location codes: 1) Reloncaví (Quillapie: 1-QI, Pichicolo: 1-PI, Caleta La Arena: 1-LA and Canutillar: 1-CN), 2) Chiloé (Canal Coldita-Piedra Blanca: 2-CB), and 3) Magallanes (Isla Peel: 3-IP). ${ }^{*} P<0.05$ after correction with sequential Bonferroni correction.

\begin{tabular}{lcclcc}
\hline & 1-PI & $1-\mathrm{LA}$ & $1-\mathrm{CN}$ & 2-CB & 3-IP \\
\hline 1-QI & $0.0191^{*}$ & $0.0390^{*}$ & $0.0305^{*}$ & $0.0787^{*}$ & $0.0323^{*}$ \\
1-PI & & $0.0650^{*}$ & 0.0049 & $0.0255^{*}$ & $0.0146^{*}$ \\
1-LA & & & $0.0712^{*}$ & $0.1112^{*}$ & $0.0740^{*}$ \\
1-CN & & & & $0.0196^{*}$ & $0.0245^{*}$ \\
2-CB & & & & & $0.0250^{*}$ \\
\hline
\end{tabular}

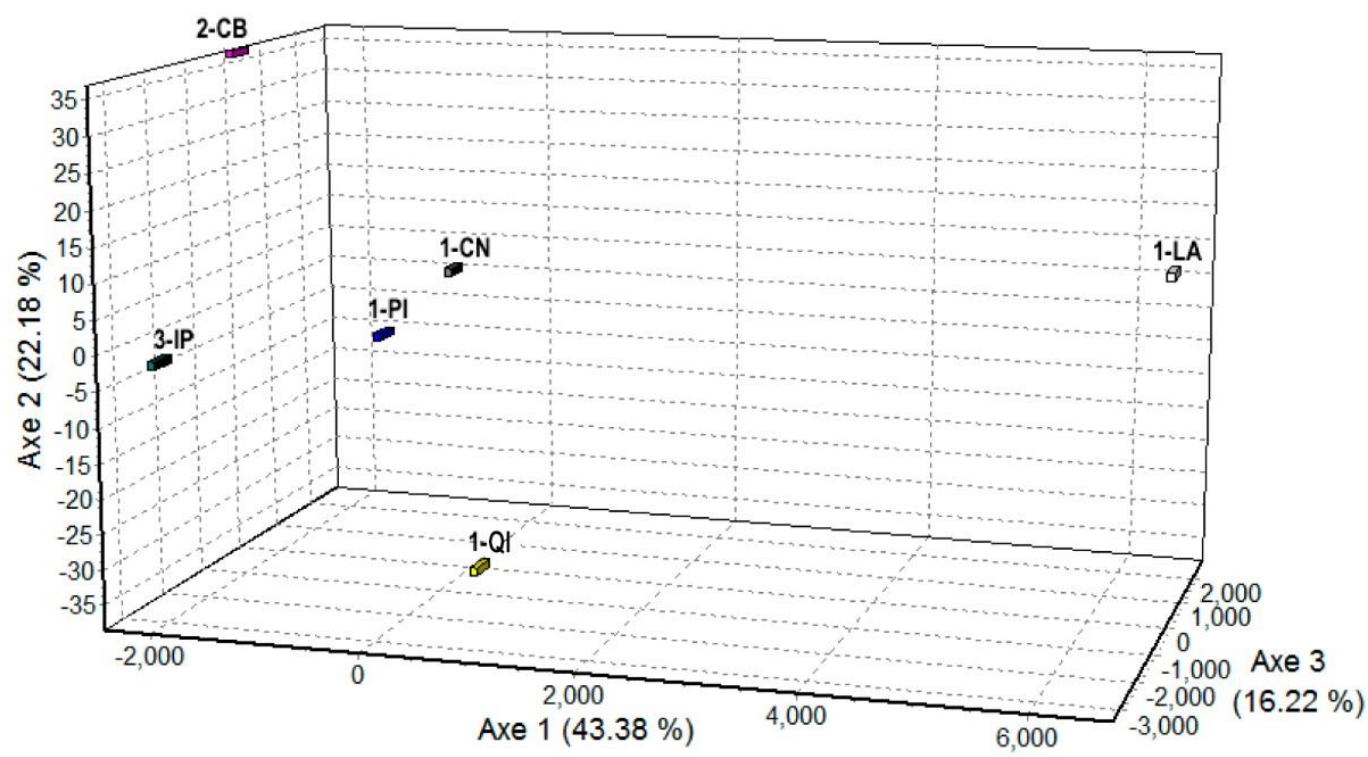

Figure 1. Three-dimensional factorial correspondence analysis plot (3D-FCA) for the six blue mussel (Mytilus chilensis) populations in southern Chile. Sample codes are indicated in Table 2.

all nine SSR loci across the six sampling locations suggests lower genetic diversity than in other SSR studies of Mytilus (Diz \& Presa, 2009; Shields et al., 2010). This is also evident from the global levels of observed and expected heterozygosities ( $\mathrm{Ho}: 0.395$ and $H e$ : 0.674) (Table 1). For example, in locus Mgu3, twelve alleles were found in Spain (Diz \& Presa, 2009) and in a hybrid zone in Canada (Shields et al., 2010), while in this study we found only six alleles.

The genetic diversity range $(0.330 \leq \mathrm{He} \leq 0.903)$ in Mytilus chilensis from the zone studied was wider than observed in M. galloprovincialis from Galicia, Spain $(0.72 \leq \mathrm{He} \leq 0.80)$ as assessed with six SSR loci (Diz $\&$ Presa, 2008). But the observed heterozygosity in this study exceeds that reported for allozymes in the same species and area $(H o=0.29)$ (Toro et al., 2006), as expected due to the highly polymorphic nature of SSR.

Deviations from HWE as shown by positive $F_{I S}$ values observed at several loci, at many sites, revealed heterozygote deficiencies. Toro et al. (2006) also reported widespread heterozygote deficiencies in population STRUCTURE studies in the same species and area using allozymes. Null alleles cause heterozygous individuals to appear homozygous if they carry a visible allele and the null allele (Brookfield, 1996). This is the best-known reason for underestimation of heterozygosity with microsatellites (Shields et al., 2010) and a common phenomenon in marine bivalve population genetics (Chapuis \& Estoup, 2007). Although we used only loci with $<5 \%$ of nonamplifying individuals (putative null allele homozygotes) (Dąbrowski et al., 2014), null alleles could be a reason for the heterozygote deficiencies observed.

The heterologous nature of the microsatellites used in this study -SSR developed for M. edulis, M. trossulus, and M. galloprovincialis were applied to Chilean blue mussels- could explain the presence of null alleles. Using the SSR developed in M. chilensis, not available 

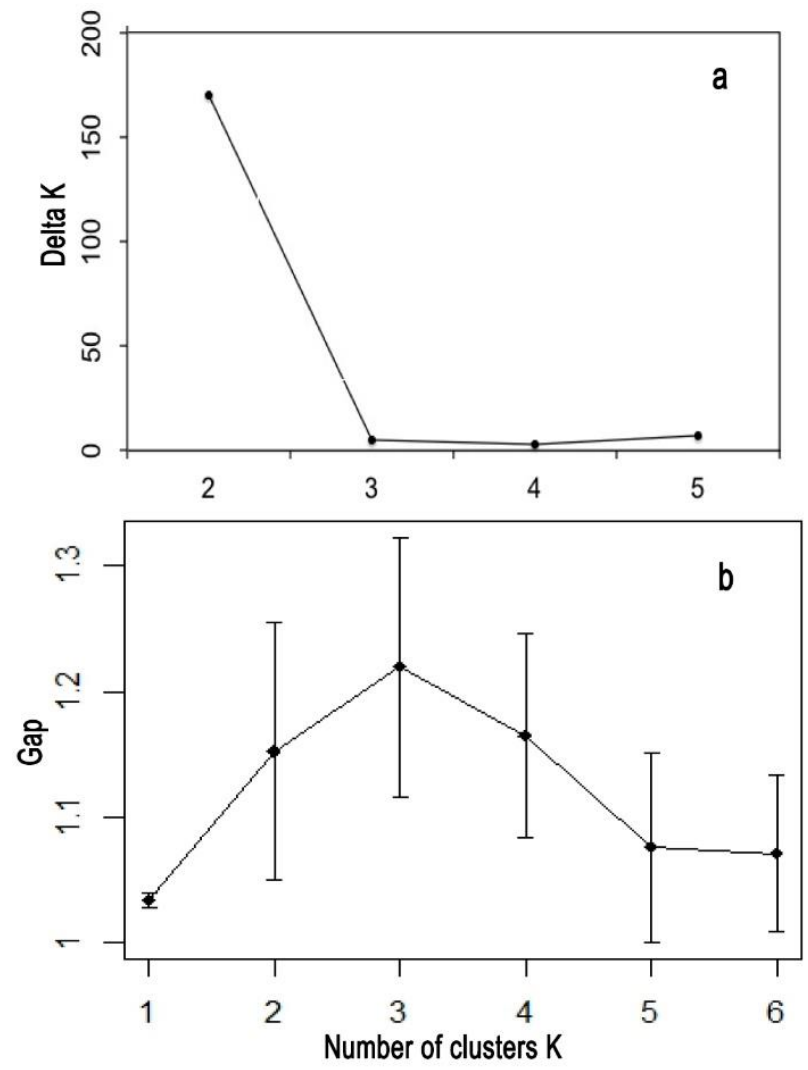

Figure 2. Number of clusters identified by a) Parametric approach implemented in STRUCTURE. Plot of the Delta $\mathrm{K}$ calculated as $\Delta K=\frac{\text { mean }\left|L^{\prime \prime}(K)\right|}{s d[L(K)]}$. The modal value of this distribution is the true $\mathrm{K}$ or the uppermost level of structure, b) non-parametric approach implemented in AWclust. Plot of the gap statistics between the observed and expected Wk results for $\mathrm{K}=1-6$ in M. chilensis. The largest gap indicates the most appropriate number of clusters for the data.

until after the completion of this experimental work, may have reduced the frequency of null alleles found (Ouagajjou et al., 2011). However, these species are genetically and phenotypically close in both hemispheres, as evidenced by the controversy over the taxonomic status of the Chilean blue mussel and the widely-described presence of null alleles in Mytilus SSR (Presa et al., 2002; Gardeström et al., 2007; Yu \& Li, 2007; Shields et al., 2010; Ouagajjou et al., 2011). Also, in other studies in the literature, correcting allele frequencies for null alleles between Mytilus populations did not change the results of statistical tests to estimate population differentiation (Gardeström et al., 2007; Diz \& Presa, 2008) or had a only minor effect on the population differentiation estimates, genetic distance determinations, and allocation of individuals to populations (Hauser et al., 2006; Chapuis \& Estoup, 2007). Given the above, along with the consideration that null alleles may not be the only reason for the observed heterozygote deficiencies, we decided not to correct the allele frequencies. Other possible reasons for heterozygote deficiencies found in Mytilus population studies are, among others, inbreeding, aneuploidy, molecular imprinting, and selection (Beaumont, 1991; Toro et al., 2006; Diz \& Presa, 2009). Although the relatedness between pairs of individuals from the same site was significantly higher than between individuals from different sites, in both cases relatedness was no higher than expected by chance (data not shown), providing no evidence of mating between related individuals (inbreeding).

The results of the microsatellite analyses revealed a common distribution of alleles between blue mussel locations in southern Chile. The global $F_{S T}(0.040)$ obtained in this survey was low but significant, and it is within the range reported by Toro et al. (2004) using allozymes $\left(F_{S T}=0.03\right)$, although it is higher than the value reported by Cárcamo et al. (2005), also using allozymes $\left(F_{S T}=0.012\right)$, and those found in mussel populations on the Iberian Peninsula $\left(F_{S T}=0.0240\right.$ and 0.0122) using microsatellites. However, a greater differentiation between localities cannot be discounted due to cryptic allelic homoplasy described for SSR markers (Diz \& Presa, 2008, 2009).

Although individuals taken from seed collection centers in zones 1 and 2 are intended for transport to grow-out centers and never will spawn in the place where they were recruited, they account for the composition of the fixed individuals in each location and may be informative regarding the location's genetic diversity and differentiation. Despite the geographical barriers of the coastline (fjords) and the considerable geographical distance between the most southern sample from Isla Peel (3-IP) in zone 3 and the Reloncaví and the Chiloé zones (zones 1 and 2 respectively), the mussel's reproductive system (external fertilization), the prolonged pelagic larval stage of this species (40-45 days) (Toro et al., 2004), the intense aquaculture activities in the Reloncaví and Chiloé zones (transportation of juveniles from seed collection centers to ongrowing centers), and the ocean currents (Cape Horn and Chilean Coastal Current) (Strub et al., 1998) promote dispersal, preventing higher levels of genetic differentiation.

Furthermore, in studies of other bivalves in the area with lower production levels than Mytilus chilensis, such as the clam (Venus antiqua) and the ribbed mussel (Aulacomya atra) (Mena et al., 2001), higher genetic differentiation values were found using allozymes $\left(F_{S T}\right.$ $=0.107$ and 0.147 , respectively). This finding led us to infer that some of the genetic homogeneity between locations in the current study could be attributed to the 
Table 3. Number of blue mussel (Mytilus chilensis) individuals in each location (n) and proportion of membership of individuals from each location to each of: a) the two clusters inferred by STRUCTURE, and b) the three clusters inferred by AWclust. Sample codes are indicated in Table 2.

\begin{tabular}{lccc}
\hline $\mathrm{a}$ & \multicolumn{3}{c}{$\begin{array}{c}\text { STRUCTURE-inferred } \\
\text { clusters }\end{array}$} \\
\hline Locations & $\mathrm{n}$ & $\mathrm{I}$ & $\mathrm{II}$ \\
\hline 1-QI & 50 & 0.391 & 0.609 \\
1-PI & 50 & 0.623 & 0.377 \\
1-LA & 50 & 0.034 & 0.966 \\
1-CN & 50 & 0.731 & 0.269 \\
2-CB & 50 & 0.824 & 0.176 \\
3-IP & 50 & 0.634 & 0.366 \\
\hline
\end{tabular}

\begin{tabular}{lllll}
\hline \multirow{b}{*}{$\mathrm{b}$} & \multicolumn{4}{c}{ AWclust-inferred clusters } \\
\hline Locations & $\mathrm{n}$ & $\mathrm{I}$ & $\mathrm{II}$ & $\mathrm{III}$ \\
\hline 1-QI & 50 & 0.26 & 0.16 & 0.58 \\
1-PI & 50 & 0.42 & 0.24 & 0.34 \\
1-LA & 50 & 0.08 & 0.20 & 0.72 \\
1-CN & 50 & 0.32 & 0.46 & 0.22 \\
2-CB & 50 & 0.48 & 0.36 & 0.16 \\
3-IP & 50 & 0.26 & 0.36 & 0.38 \\
\hline
\end{tabular}

effect of extensive seed transfer, as reported in Galicia (Diz \& Presa, 2009). The extent of pairwise genetic differentiation among the six sampled locations was small, but pairwise $F_{S T}$ showed significant allelic differentiation, revealing unpatterned genetic heterogeneity among the local population, or genetic patchiness. This effect results in geographically close populations that may differ genetically as much as very distant populations, as has been reported in other marine organisms (Larson \& Julian, 1999; Appleyard et al., 2002).

The numbers of clusters inferred from the parametric $(K=2)$ and non-parametric methods $(K=3)$ were different; however, they were not in conflict because the gap statistic to determine the discrete number of clusters in AWclust gave widely overlapping error bars for $\mathrm{K}=2,3$, and 4 , providing a better resolution of the population structure (Fig. 2b). The parametric clustering approach in STRUCTURE provided more information (i.e., about the probability an individual's membership in each cluster), but it relies on assumptions like HWE that were not always met during this study. Therefore, the non-parametric method for population structure analysis is more appropriate. According to Gao \& Starmer (2008), the two methods can be complementary in structure analysis.

Our results for blue mussels using nine microsatellite loci indicate low inbreeding levels and lower levels of genetic diversity in Chile than in Spain or Canada; this latter is recognized as a hybrid zone, so higher levels of allelic richness and heterozygosity are expected. Furthermore, we found low but significant genetic differentiation among locations in southern Chile. These findings may be partly explained by reproduction conditions, prolonged pelagic larval stage, oceanographic conditions, and intense Chilean blue mussel aquaculture in the region.

\section{ACKNOWLEDGEMENTS}

This research was supported by CONICYT, FONDECYT/Regular $\mathrm{N}^{\circ} 1130302$, and Universidad de Chile (Vice-Rectoría de Investigación-Proyecto Domeyko-Alimentos). The authors thank Dr. Carlos Varela (Universidad de Los Lagos), for contacts with the shellfish cultivation industry; Eugenio Yokota and Julio Bañados from Granja Marina Chauquear, Marcela Cárcamo from Cultivos Quillaipe, and Armando Salinas from Aguas del Sur S.A., who kindly allowed us to perform the sampling at their farms; José Villarroel, for collecting the wild population sample; Dr. Elie Poulin (Universidad de Chile, Facultad de Ciencias), for access to the NanoDrop spectrophotometer; Andrea Bravo, for helping with DNA extraction; and Dr. Juhani Pirhonen, for critical review of this manuscript.

\section{REFERENCES}

Abbott, R., D. Albach, S. Ansell, J.W. Arntzen, S.J.E. Baird, N. Bierne et al., 2013. Hybridization and speciation. J. Evol. Biol., 26(2): 229-246.

Appleyard, S.A., R.D. Ward \& R. Williams. 2002. Population structure of the Patagonian toothfish around Heard, McDonald and Macquarie Islands. Antarct. Sci., 14(04): 364-373.

Astorga, M.P. 2014. Genetic considerations for mollusc production in Aquaculture: current state of knowledge. Front. Genet., 5: 1-6.

Astorga, M.P. \& J. Toro. 2010. Genetic differentiation in Mytilus (Mollusca: Bivalvia) in the Chilean coast. XIV Congreso Latinoamericano de Genética-ALAG. Sociedad Chilena de Genética- SOCHIGEN. Viña del Mar, 723: 419 pp.

Bagnara, M. \& G. Maltraín. 2008. Descripción del sector mitilicultor en la Región de Los Lagos, Chile: 
evolución y proyecciones. In: A. Lovatelli (ed.). Estado actual del cultivo y manejo de moluscos bivalvos y su proyección futura: factores que afectan su sustentabilidad en América Latina. Actas de pesca y acuicultura. Taller Técnico-Regional de la FAO, 20-24 de Agosto de 2007. Puerto Montt, Chile, 12: 189-198.

Beaumont, A.R. 1991. Genetic studies of laboratory reared mussels, Mytilus edulis: heterozygote deficiencies, heterozygosity and growth. Biol. J. Linn. Soc., 44(3): 273-285.

Belkhir, K., V. Castric \& F. Bonhomme. 2002. Program Note Identix: a software to test for relatedness in a population using permutation methods. Mol. Ecol. Notes, 2: 611-614.

Belkhir, K., P. Borsa, L. Chikhi, N. Raufaste \& F. Bonhomme. 1996. Genetix 4.05, Logiciel sous WindowsTM pour la génetique des populations. Laboratorie Génome Populations Interactions CNSR UMR 5000. Université de Montpellier. MontpellierFrance. [http://www.univ-montp2.fr/ genetix/genetix/ genetix.htm]. Reviewed: 27 January 2015.

Borsa, P., V. Rolland \& C. Daguin-Thiébaut. 2012. Genetics and taxonomy of Chilean smooth-shelled mussels, Mytilus spp. (Bivalvia: Mytilidae). C. R. Biol., 335(1): 51-61.

Boxshall, G.A., J. Mees, M.J. Costello, F. Hernandez, S. Gofas, B.W. Hoeksema, et al., 2014. World register of marine species (WoRMS). Society for the Management of Electronic Biodiversity Data (SMEBD). [http://www.marinespecies.org.]. Reviewed: 27 January 2015.

Briones, C., P. Presa, M. Pérez, A. Pita \& R. Guiñez. 2013. Genetic connectivity of the ecosystem engineer Perumytilus purpuratus north to the $32^{\circ} \mathrm{S}$ Southeast Pacific ecological discontinuity. Mar. Biol., 160(12): 3143-3156.

Brookfield, J.F.Y. 1996. A simple method for estimating null allele frequency from heterozygote deficiency. Mol. Ecol., 5: 453-455.

Cárcamo, C., A.S. Comesaña, F.M. Winkler \& A. Sanjuan. 2005. Allozyme identification of mussels (Bivalvia: Mytilus) on the Pacific coast of South America. J. Shellfish Res., 24: 1101-1115.

Chapuis, M.P. \& A. Estoup. 2007. Microsatellite null alleles and estimation of population differentiation. Mol. Biol. Evol., 24(3): 621-631.

Cruz, F., M. Pérez \& P. Presa. 2005. Distribution and abundance of microsatellites in the genome of bivalves. Gene, 346: 241-247.

Dąbrowski, M.J., S. Bornelöv, M. Kruczyk, N. Baltzer \& J. Komorowski. 2014. True null allele detection in microsatellite loci: a comparison of methods, assessment of difficulties and survey of possible improvements. Mol. Ecol. Res., 15(3): 477-488.
Diz, A.P. \& P. Presa. 2008. Regional patterns of microsatellite variation in Mytilus galloprovincialis from the Iberian Peninsula. Mar. Biol., 154(2): 277286.

Diz, A.P. \& P. Presa. 2009. The genetic diversity pattern of Mytilus galloprovincialis in Galician Rías (NW Iberian Estuaries). Aquaculture, 287(3-4): 278-285.

Earl, D.A \& B.M. von Holdt. 2012. STRUCTURE harvester: a website and program for visualizing structure output and implementing the Evanno method. Conserv. Genet. Res., 4(2): 359-361.

Evanno, G., S. Regnaut \& J. Goudet. 2005. Detecting the number of clusters of individuals using the software STRUCTURE: a simulation study. Mol. Ecol., 14(8): 2611-2620.

Falush, D., M. Stephens \& J.K. Pritchard. 2007. Inference of population structure using multilocus genotype data: dominant markers and null alleles. Mol. Ecol. Notes, 7(4): 574-578.

Food and Agriculture Organization of the United Nations (FAO). 2015. Global statistical collections. [http:// www.fao.org/fishery/statistics/en.]. Reviewed: 27 January 2015.

Global Aquaculture Alliance (GAA). 2013. Best aquaculture practices certification. Mussel farms. BAP Standards, Guidelines. USA: Global Aquaculture Alliance, $16 \mathrm{pp}$.

Gao, X. \& J. Starmer. 2008. AWclust: point-and-click software for non-parametric population STRUCTURE analysis. BMC Bioinformatics, 9(1): 77.

Gardeström, J., R.T. Pereyra \& C. André. 2007. Characterization of six microsatellite loci in the Baltic blue mussel Mytilus trossulus and cross-species amplification in North Sea Mytilus edulis. Conserv. Genet., 9(4): 1003-1005.

Gazeau, F., L.M. Parker, S. Comeau, J.P. Gattuso, W.A. O'Connor, S. Martin, H.O Pörtner \& P.M. Ross. 2013. Impacts of ocean acidification on marine shelled molluscs. Mar. Biol., 160(8): 2207-2245.

Glaubitz, J.C. 2004. Convert: a user-friendly program to reformat diploid genotypic data for commonly used population genetic software packages. Mol. Ecol. Notes, 4(2): 309-310.

Guo, S.W. \& E.A. Thompson. 1992. A Monte-Carlo Method for combined segregation and linkage analysis. Am. J. Hum. Genet., 51(5): 1111-1126.

Guyomard, R., M. Boussaha, F. Krieg, C. Hervet \& E. Quillet. 2012. A synthetic rainbow trout linkage map provides new insights into the salmonid whole genome duplication and the conservation of synteny among teleosts. BMC Genet., 13(1): 15. 
Hauser, L., T.R. Seamons, M. Dauer, K.A. Naish \& T.P. Quinn. 2006. An empirical verification of population assignment methods by marking and parentage data: hatchery and wild steelhead (Oncorhynchus mykiss) in Forks Creek, Washington, USA. Mol. Ecol., 15(11): 3157-3173.

He, L., Y.N. Xie, W. Lu, Y. Wang, L.L. Chen, P.B. Mather, Y.L. Zhao, Y.P. Wang \& Q. Wang. 2012. Genetic diversity in three redclaw crayfish (Cherax quadricarinatus, von Martens) lines developed in culture in China. Aquacult. Res., 43(1): 75-83.

Hernández, J.M. \& L.E. González. 1976. Observaciones sobre el comportamiento de mitílidos chilenos en cultivo suspendido: I Chorito Mytilus chilensis (Hupe, 1854). [http://books.google.cl/books?id=kZy5HAAA CAAJ]. Reviewed: 25 January 2015.

Holm, S. 1979. A Simple sequentially rejective multiple test procedure. Scand. J. Stat., 6(2): 65-70.

Inoue, K., J.H. Waite, M. Matsuoka, S. Odo \& S. Harayama. 1995. Interspecific variations in adhesive protein sequences of Mytilus edulis, M. galloprovincialis, and M. trossulus. Biol. Bull., 189(3): 370375.

Kijewski, T., J.W.M. Wijsman, H. Hummel \& R. Wenne. 2009. Genetic composition of cultured and wild mussels Mytilus from The Netherlands and transfers from Ireland and Great Britain. Aquaculture, 287(3-4): 292-296.

Lallias, D., R. Stockdale, P. Boudry, S. Lapegue \& A.R. Beaumont. 2009. Characterization of ten microsatellite loci in the blue mussel Mytilus edulis. J. Shellfish Res., 28(3): 547-551.

Larraín, M.A. 2012. Utilización de marcadores genético moleculares en calidad e inocuidad de los alimentos. Aplicaciones en trazabilidad y denominación de origen geográfico de Mytilus chilensis. Ph.D. Thesis. Universidad de Santiago de Chile, Santiago, 101 pp.

Larraín, M.A., N.F. Díaz, C. Lamas, C. Uribe \& C. Araneda. 2014. Traceability of mussel (Mytilus chilensis) in Southern Chile using microsatellite molecular markers and assignment algorithms. Exploratory survey. Food Res. Int., 62(0): 104-110.

Larraín, M.A., N.F. Díaz, C. Lamas, C. Vargas \& C. Araneda. 2012. Genetic composition of Mytilus species in mussel populations from Southern Chile. Lat. Am. J. Aquat. Res., 40(4): 1077-1084.

Larson, R.J. \& R.M. Julian. 1999. Spatial and temporal genetic patchiness in marine populations and their implications for fisheries management. CalCOFI Rep., 40: 94-99.

Liu, Z.J. \& J.F. Cordes. 2004. DNA marker technologies and their applications in aquaculture genetics. Aquaculture, 238(1-4): 1-37.
Mantel, N. 1967. The detection of disease clustering and a generalized regression approach. Cancer Res., 27(2 Part 1): 209-220.

Mena, C., C. González, E. Clasing \& M. Garllardo. 2001. Variabilidad genética en Aulacomya atra (Molina, 1782) en el sur de Chile. Cienc. Tecnol. Mar, 24: 7179.

Mohanty, P., Lakshman S., Bindu R.P., P. Jayasankar \& P. Das. 2014. Genetic divergence in indian populations of M. rosenbergii using microsatellite markers. Aquacult. Res., 30: 1-10.

Ouagajjou, Y. \& P. Presa. 2015. The connectivity of Mytilus galloprovincialis in northern Morocco: a gene flow crossroads between continents. Estuar. Coast. Shelf Sci., 152: 1-10.

Ouagajjou, Y., P. Presa, M. Astorga \& M. Pérez. 2011. Microsatellites of Mytilus chilensis: a genomic print of its taxonomic status within Mytilus sp. J. Shellfish Res., 30(2): 325-330.

Oyarzún, P., J.E. Toro, O. Garrido, C. Briones \& R. Guiñez. 2014. Differences in sperm ultrastructure between Mytilus chilensis and Mytilus galloprovincialis (Bivalvia, Mytilidae): could be used as a taxonomic trait? Lat. Am. J. Aquat. Res., 42(1): 172179.

Park, S.D.E. 2001. Trypanotolerance in west African cattle and the population genetic effects of selection. Ph.D. Thesis. University of Dublin. [http://animalgenomics. ucd.ie/sdepark/ms-toolkit/]. Reviewed: 25 January 2015.

Perez, M., R. Guiñez, A. Llavona, J.E. Toro, M. Astorga \& P. Presa. 2008. Development of microsatellite markers for the ecosystem bioengineer mussel Perumytilus purpuratus and cross-priming testing in six Mytilinae genera. Mol. Ecol. Resour., 8(2): 449451.

Presa, P., M. Pérez \& A. Diz. 2002. Polymorphic microsatellite markers for blue mussels (Mytilus spp.). Conserv. Genet., 3: 441-443.

Pritchard, J.K., M. Stephens \& P. Donnelly. 2000. Inference of population structure using multilocus genotype data. Genetics, 155(2): 945-959.

Queller, D.C. \& K.F. Goodnight. 1989. Estimating relatedness using genetic markers. Evolution, 43 (2): 258-275.

Raymond, M. \& F. Rousset. 1995. Genepop (Version 1.2): population genetics software for exact tests and ecumenicism. J. Hered., 86(3): 248-249.

Rice, W.R. 1989. Analyzing tables of statistical tests. Evolution, 43(1): 223-225. 
Riisgard, H.U., D. Pleissner, K. Lundgreen \& P.S. Larsen. 2013. Growth of mussels Mytilus edulis at algal (Rhodomonas salina) concentrations below and above saturation levels for reduced filtration rate. Mar. Biol. Res., 9(10): 1005-1017.

Rousset, F. 2008. Genepop'007: a complete reimplementation of the Genepop software for Windows and Linux. Mol. Ecol. Resour., 8(1): 103-106.

Santaclara, F.J., M. Espiñeira, A.G. Cabado, A. Aldasoro, N. Gonzalez-Lavín \& J.M. Vieites. 2006. Development of a method for the genetic identification of mussel species belonging to Mytilus, Perna, Aulacomya, and other genera. J. Agric. Food Chem., 54(22): 8461-8470.

Seguel, M. 2011. Evaluation of the taxonomic status of Mytilus chilensis using the mitochondrial gene citochrome $\mathrm{C}$ oxidase subunit $\mathrm{I}$ (COI). XXXI Congreso de Ciencias del Mar, Viña del Mar, 220 pp.

Servicio Nacional de Pesca y Acuicultura (SERNAPESCA). 2015. Anuario Estadístico de Pesca-2013. Servicio Nacional de Pesca y Acuicultura (disponible online https://www.sernapesca.cl/index. php?option $=$ com_content $\&$ task=view\&id $=1806 \&$ Ite mid=889). Reviewed: 27 January 2015.

Shields, J.L., J.W. Heath \& D.D. Heath. 2010. Marine landscape shapes hybrid zone in a broadcast spawning bivalve: introgression and genetic structure in Canadian west coast Mytilus. Mar. Ecol. Prog. Ser., 399: 211-223.

Strub, P.T., J.M. Mesías, V. Montecino \& J. Rutllant. 1998. Coastal ocean circulation off western South América. In: A.R. Robinson \& K.H. Brink (eds.). The Sea, 11: 273-313.

Tarifeño, E., R. Galleguillos, J. Gardner, I. Lépez, D. Arriagada, A. Llanos, S. Astete, S. Ferrada, S. Rodríguez \& S. Gacitúa. 2005. Presencia de mejillón, Mytilus galloprovincialis (Lmk) (Bivalvia, Mollusca) en las costas de la región del Biobío, Chile. XI Congreso Latinoamericano de Ciencias del Mar. Viña del Mar. Chile. [http://www.xxvcongreso2005.ucv. cl/]. Reviewed: 25 January 2015.

Toro, J.E. 1998. PCR-based nuclear and mtDNA markers and shell morphology as an approach to study the taxonomic status of the chilean blue mussel, Mytilus chilensis (Bivalvia). Aquat. Living Resour., 11(5): 347-353.

Received: 18 May 2015; Accepted: 17 August 2015
Toro, J.E., J.A. Ojeda \& A.M. Vergara. 2004. The genetic STRUCTURE of Mytilus chilensis (Hupé, 1854) Populations along the Chilean coast based on RAPDs analysis. Aquacult. Res., 35(15): 1466-1471.

Toro, J.E., R.J. Thompson \& D.J. Innes. 2006. Fertilization success and early survival in pure and hybrid larvae of Mytilus edulis (Linnaeus, 1758) and M. trossulus (Gould, 1850) from laboratory crosses. Aquacult. Res., 37(16): 1703-1708.

Toro, J.E., G.C. Castro, J.A. Ojeda \& A.M. Vergara. 2006. Allozymic variation and differentiation in the Chilean blue mussel, Mytilus chilensis, along its natural distribution. Genet. Mol. Biol., 29(1): 174-179.

Toro, J.E., J.A. Ojeda, A.M. Vergara, G.C. Castro \& A.C. Alcapán. 2005. Molecular characterization of the chilean blue mussel Mytilus chilensis (Hupé, 1854) demonstrates evidence for the occurrence of Mytilus galloprovincialis in southern Chile. J. Shellfish Res., 24(4): 1117-1121.

Van Oosterhout, C., W.F. Hutchinson, D.P.M. Wills \& P. Shipley. 2004. MICRO-CHECKER: software for identifying and correcting genotyping errors in microsatellite Data. Mol. Ecol. Notes, 4(3): 535-538.

Vidal, R., C. Peñaloza, R. Urzua, \& J.E. Toro. 2009. Screening of ESTs from Mytilus for the detection of SSR markers in Mytilus californianus. Mol. Ecol. Resour., 9(5): 1409-1411.

Wei, K.J., A.R. Wood \& J.P.A. Gardner. 2013. Population genetic variation in the New Zealand greenshell mussel: locus-dependent conflicting signals of weak structure and high gene flow balanced against pronounced structure and high self-recruitment. Mar. Biol., 160(4): 931-949.

Weir, B.S. \& C.C. Cockerham. 1984. Estimating Fstatistics for the analysis of population STRUCTURE. Evolution, 38: 1358-1370.

Westfall, K.M. \& J.P.A. Gardner. 2010. Genetic diversity of Southern Hemisphere blue mussels (Bivalvia: Mytilidae) and identification of non-indigenous taxa. Biol. J. Linn. Soc., 101: 898-909.

Yu, Hong \& Q.I. Li. 2007. Development of EST-SSRs in the Mediterranean blue mussel, Mytilus galloprovincialis. Mol. Ecol. Notes, 7(6): 1308-1310.

Zbawicka, M., T. Sanko, J. Strand \& R. Wenne. 2014. New SNP markers reveal largely concordant clinal variation across the hybrid zone between Mytilus spp. in the Baltic Sea. Aquat. Biol., 21 (1): 25-36. 
Annex 1. Allele frequencies for nine SSR loci genotyped in blue mussels (Mytilus chilensis) from six locations in southern Chile. Zone and location codes: 1) Reloncaví (Quillaipe: 1-QI, Pichicolo: 1-PI, Caleta La Arena: 1-LA and Canutillar: 1$\mathrm{CN}$ ), 2) Chiloé (Canal Coldita-Piedra Blanca: 2-CB), and 3) Magallanes (Isla Peel: 3-IP).

\begin{tabular}{|c|c|c|c|c|c|c|c|}
\hline \multirow{2}{*}{$\begin{array}{l}\text { Allele size }[\mathrm{bp}] \\
\text { Locus }\end{array}$} & & \multicolumn{6}{|c|}{ Location } \\
\hline & & 1-QI & 1-PI & 1-LA & $1-\mathrm{CN}$ & 2-CB & 3-IP \\
\hline \multirow[t]{15}{*}{ Mgul } & 115 & 4.00 & - & 17.00 & 2.00 & 6.00 & 3.00 \\
\hline & 151 & 6.00 & 3.00 & 2.00 & 3.00 & 14.00 & 8.00 \\
\hline & 153 & 6.00 & 12.00 & 24.00 & 9.00 & 18.00 & 19.00 \\
\hline & 155 & 21.00 & 17.00 & 8.00 & 8.00 & 7.00 & 26.00 \\
\hline & 163 & 6.00 & 12.00 & 3.00 & 13.00 & 4.00 & 1.00 \\
\hline & 171 & 2.00 & 1.00 & 6.00 & - & 3.00 & 3.00 \\
\hline & 173 & 6.00 & 4.00 & 6.00 & 4.00 & - & 2.00 \\
\hline & 175 & 10.00 & 2.00 & 10.00 & 13.00 & 16.00 & 2.00 \\
\hline & 177 & 11.00 & 12.00 & 14.00 & 24.00 & 15.00 & 11.00 \\
\hline & 181 & 13.00 & 20.00 & 8.00 & 11.00 & - & 10.00 \\
\hline & 187 & 7.00 & 5.00 & - & 3.00 & 4.00 & 6.00 \\
\hline & 189 & 2.00 & 6.00 & 1.00 & - & 2.00 & - \\
\hline & 197 & 1.00 & 2.00 & 1.00 & 6.00 & 8.00 & 4.00 \\
\hline & 217 & 5.00 & 2.00 & - & 2.00 & 3.00 & 5.00 \\
\hline & 225 & - & 2.00 & - & 2.00 & - & - \\
\hline \multirow[t]{6}{*}{ Mgu3 } & 141 & - & 1.00 & - & - & - & - \\
\hline & 143 & 31.00 & 62.00 & 1.00 & 74.49 & 83.00 & 58.00 \\
\hline & 147 & 51.00 & 36.00 & 47.00 & 23.47 & 15.00 & 33.00 \\
\hline & 151 & - & - & 48.00 & - & - & - \\
\hline & 157 & 9.00 & - & 1.00 & 1.02 & 1.00 & 7.00 \\
\hline & 159 & 9.00 & 1.00 & 3.00 & 1.02 & 1.00 & 2.00 \\
\hline \multirow[t]{10}{*}{ MT203 } & 178 & 36.00 & 45.00 & 25.00 & 34.00 & 50.00 & 44.00 \\
\hline & 184 & 6.00 & 13.00 & 25.00 & 12.00 & 6.00 & 6.00 \\
\hline & 188 & 30.00 & 21.00 & 17.00 & 18.00 & 12.00 & 18.00 \\
\hline & 192 & 2.00 & 1.00 & - & 1.00 & 6.00 & - \\
\hline & 194 & 6.00 & - & 6.00 & 7.00 & 7.00 & 4.00 \\
\hline & 198 & 7.00 & 4.00 & 10.00 & 8.00 & 10.00 & 10.00 \\
\hline & 202 & 7.00 & 11.00 & 1.00 & 11.00 & 4.00 & 10.00 \\
\hline & 206 & 3.00 & 1.00 & 3.00 & 7.00 & 1.00 & 5.00 \\
\hline & 216 & 3.00 & 3.00 & 9.00 & 2.00 & 4.00 & 2.00 \\
\hline & 220 & - & 1.00 & 4.00 & - & - & 1.00 \\
\hline \multirow[t]{4}{*}{$M T 282$} & 335 & 28.00 & 41.00 & 33.00 & 33.00 & 37.00 & 40.00 \\
\hline & 347 & 18.00 & 14.00 & 2.00 & 10.00 & 5.00 & 17.00 \\
\hline & 353 & 49.00 & 41.00 & 60.00 & 52.00 & 55.00 & 41.00 \\
\hline & 381 & 5.00 & 4.00 & 5.00 & 5.00 & 3.00 & 2.00 \\
\hline \multirow[t]{2}{*}{$M g 15$} & 115 & 9.78 & 2.08 & 3.06 & 7.14 & 2.04 & 3.00 \\
\hline & 120 & 38.04 & 31.25 & 32.65 & 29.59 & 28.57 & 43.00 \\
\hline
\end{tabular}


Continuation

\begin{tabular}{|c|c|c|c|c|c|c|c|}
\hline \multirow{2}{*}{$\begin{array}{l}\text { Allele size }[\mathrm{bp}] \\
\text { Locus }\end{array}$} & & \multicolumn{6}{|c|}{ Location } \\
\hline & & 1-QI & 1-PI & 1-LA & $1-\mathrm{CN}$ & 2-CB & 3-IP \\
\hline & 123 & 10.87 & 30.21 & 35.71 & 36.73 & 39.80 & 29.00 \\
\hline & 135 & 41.30 & 36.46 & 28.57 & 26.53 & 29.59 & 25.00 \\
\hline \multirow[t]{11}{*}{$M g 56$} & 247 & - & - & - & - & 1.00 & - \\
\hline & 294 & 1.04 & 6.12 & 8.00 & 2.04 & 6.00 & 2.00 \\
\hline & 301 & 7.29 & 4.08 & 7.00 & 8.16 & 1.00 & 3.00 \\
\hline & 337 & 2.08 & 9.18 & 4.00 & 5.10 & 11.00 & 9.00 \\
\hline & 344 & 26.04 & 32.65 & 26.00 & 41.84 & 51.00 & 30.00 \\
\hline & 351 & 45.83 & 24.49 & 46.00 & 26.53 & 17.00 & 32.00 \\
\hline & 372 & 3.13 & 2.04 & 1.00 & 5.10 & 3.00 & 2.00 \\
\hline & 399 & - & 1.02 & - & 1.02 & 1.00 & 1.00 \\
\hline & 425 & 4.17 & 3.06 & 3.00 & 1.02 & 3.00 & 4.00 \\
\hline & 441 & 10.42 & 13.27 & 4.00 & 8.16 & 4.00 & 17.00 \\
\hline & 464 & - & 4.08 & 1.00 & 1.02 & 2.00 & - \\
\hline \multirow[t]{10}{*}{ Med737 } & 122 & 1.00 & - & - & - & - & - \\
\hline & 134 & - & 1.00 & 1.00 & 3.00 & - & - \\
\hline & 140 & 57.00 & 40.00 & 52.00 & 51.00 & 13.00 & 19.00 \\
\hline & 142 & 4.00 & - & 7.00 & 4.00 & 4.00 & 1.00 \\
\hline & 146 & 18.00 & 35.00 & 21.00 & 22.00 & 35.00 & 8.00 \\
\hline & 152 & 8.00 & 3.00 & 2.00 & 3.00 & 2.00 & 6.00 \\
\hline & 164 & 8.00 & 12.00 & 11.00 & 14.00 & 29.00 & 37.00 \\
\hline & 168 & 2.00 & 4.00 & 2.00 & 1.00 & 13.00 & 12.00 \\
\hline & 174 & 2.00 & 3.00 & 4.00 & - & 4.00 & 13.00 \\
\hline & 184 & - & 2.00 & - & 2.00 & - & 4.00 \\
\hline \multirow[t]{5}{*}{ MIT02 } & 197 & 4.00 & 1.00 & 2.00 & 6.00 & 7.14 & 7.00 \\
\hline & 221 & 7.00 & 14.00 & 3.00 & 5.00 & 10.20 & 2.00 \\
\hline & 227 & 51.00 & 51.00 & 52.00 & 52.00 & 39.80 & 45.00 \\
\hline & 237 & 2.00 & 4.00 & 4.00 & - & 2.04 & 3.00 \\
\hline & 243 & 36.00 & 30.00 & 39.00 & 37.00 & 40.82 & 43.00 \\
\hline \multirow[t]{10}{*}{$M G E 005$} & 113 & 2.00 & - & - & - & - & - \\
\hline & 119 & 2.00 & 2.00 & - & - & 1.00 & - \\
\hline & 122 & 3.00 & 3.00 & 3.00 & - & 3.00 & 5.00 \\
\hline & 125 & 4.00 & 7.00 & 5.00 & 7.00 & 3.00 & 4.00 \\
\hline & 128 & 2.00 & 2.00 & 1.00 & - & 2.00 & 3.00 \\
\hline & 134 & 5.00 & - & 3.00 & 11.00 & 3.00 & 2.00 \\
\hline & 137 & 79.00 & 82.00 & 83.00 & 77.00 & 83.00 & 85.00 \\
\hline & 140 & 2.00 & 2.00 & 4.00 & 3.00 & 3.00 & - \\
\hline & 143 & 1.00 & 2.00 & 1.00 & 1.00 & 2.00 & 1.00 \\
\hline & 149 & - & - & - & 1.00 & - & - \\
\hline
\end{tabular}


Annex 2. Diversity parameters for nine SSR loci analyzed in six mussel locations (Mytilus chilensis) from southern Chile. Sample codes are indicated in Annex 1. Note: The number of alleles $(\mathrm{Na})$, the number of private alleles $(\mathrm{Ap})$, the observed heterozygosity $(\mathrm{Ho})$, the expected heterozygosity $(\mathrm{He})$, and the fixation index $\mathrm{Fis}$ according to Weir \& Cockerham are provided for each locus and sample site. * Significant departures from Hardy-Weinberg expectations are corrected with sequential Bonferroni correction.

\begin{tabular}{|c|c|c|c|c|c|c|}
\hline Locus/Location & 1-QI & 1-PI & 1-LA & $1-\mathrm{CN}$ & 2-CB & 3-IP \\
\hline \multicolumn{7}{|l|}{ Mgu1 } \\
\hline $\mathrm{A}(\mathrm{Ap})$ & $14(0)$ & $14(0)$ & $12(0)$ & $13(0)$ & $12(0)$ & $13(0)$ \\
\hline Ho & 0.500 & 0.300 & 0.560 & 0.340 & 0.500 & 0.240 \\
\hline $\mathrm{He}$ & 0.902 & 0.886 & 0.871 & 0.883 & 0.888 & 0.866 \\
\hline Fis (W\&C) & $0.448 *$ & $0.664 *$ & $0.360 *$ & $0.617 *$ & $0.440 *$ & $0.725^{*}$ \\
\hline \multicolumn{7}{|l|}{ Mgu3 } \\
\hline A(Ap) & $4(0)$ & $4(1)$ & $5(1)$ & $4(0)$ & $4(0)$ & $4(0)$ \\
\hline Но & 0.160 & 0.040 & 0.200 & 0.041 & 0.040 & 0.100 \\
\hline $\mathrm{He}$ & 0.634 & 0.491 & 0.553 & 0.394 & 0.291 & 0.555 \\
\hline Fis (W\&C) & $0.750 *$ & $0.919 *$ & $0.641 *$ & $0.897 *$ & $0.864 *$ & $0.821^{*}$ \\
\hline \multicolumn{7}{|l|}{ MT203 } \\
\hline A (Ap) & $9(0)$ & $9(0)$ & $9(0)$ & $9(0)$ & $9(0)$ & $9(0)$ \\
\hline Ho & 0.380 & 0.420 & 0.440 & 0.420 & 0.500 & 0.560 \\
\hline $\mathrm{He}$ & 0.769 & 0.729 & 0.830 & 0.817 & 0.717 & 0.753 \\
\hline Fis (W\&C) & $0.508 *$ & $0.426^{*}$ & $0.473 *$ & $0.488 *$ & $0.305^{*}$ & $0.259 *$ \\
\hline \multicolumn{7}{|l|}{ MT282 } \\
\hline $\bar{A}(\mathrm{Ap})$ & $4(0)$ & $4(0)$ & $4(0)$ & $4(0)$ & $4(0)$ & $4(0)$ \\
\hline Но & 0.420 & 0.560 & 0.580 & 0.620 & 0.600 & 0.480 \\
\hline $\mathrm{He}$ & 0.653 & 0.649 & 0.534 & 0.614 & 0.563 & 0.649 \\
\hline Fis (W\&C) & $0.359 *$ & $0.139 *$ & -0.088 & -0.009 & -0.067 & $0.263 *$ \\
\hline \multicolumn{7}{|l|}{ Mg15 } \\
\hline$\overline{\text { A (Ap) }}$ & $4(0)$ & $4(0)$ & $4(0)$ & $4(0)$ & $4(0)$ & $4(0)$ \\
\hline Но & 0.413 & 0.396 & 0.490 & 0.469 & 0.347 & 0.380 \\
\hline $\mathrm{He}$ & 0.671 & 0.685 & 0.690 & 0.709 & 0.679 & 0.674 \\
\hline Fis (W\&C) & $0.387 *$ & $0.425^{*}$ & $0.293 *$ & $0.341 *$ & $0.492 *$ & $0.439 *$ \\
\hline \multicolumn{7}{|l|}{ Mg56 } \\
\hline A (Ap) & $8(0)$ & $10(0)$ & $9(0)$ & $10(0)$ & $11(1)$ & $9(0)$ \\
\hline Но & 0.521 & 0.469 & 0.460 & 0.408 & 0.380 & 0.580 \\
\hline $\mathrm{He}$ & 0.710 & 0.807 & 0.712 & 0.743 & 0.698 & 0.775 \\
\hline Fis (W\&C) & $0.269 *$ & $0.421 *$ & $0.357^{*}$ & $0.453 *$ & $0.458^{*}$ & $0.254 *$ \\
\hline \multicolumn{7}{|l|}{ Med737 } \\
\hline A (Ap) & $8(1)$ & $8(0)$ & $8(0)$ & $8(0)$ & $7(0)$ & $8(0)$ \\
\hline Но & 0.634 & 0.706 & 0.673 & 0.675 & 0.764 & 0.792 \\
\hline $\mathrm{He}$ & 0.595 & 0.650 & 0.630 & 0.628 & 0.719 & 0.758 \\
\hline Fis (W\&C) & $0.245^{*}$ & $0.152 *$ & $0.378 *$ & $0.499 *$ & $0.269^{*}$ & $0.371 *$ \\
\hline \multicolumn{7}{|l|}{ MIT02 } \\
\hline A (Ap) & $5(0)$ & $5(0)$ & $5(0)$ & $4(0)$ & $5(0)$ & $5(0)$ \\
\hline Ho & 0.280 & 0.300 & 0.400 & 0.320 & 0.449 & 0.440 \\
\hline $\mathrm{He}$ & 0.769 & 0.729 & 0.830 & 0.817 & 0.717 & 0.753 \\
\hline Fis (W\&C) & $0.543 *$ & $0.530 *$ & $0.313^{*}$ & $0.463^{*}$ & 0.328 & 0.284 \\
\hline \multicolumn{7}{|l|}{ MGE005 } \\
\hline$\overline{\mathrm{A}(\mathrm{Ap})}$ & $9(1)$ & $7(0)$ & $7(0)$ & $6(1)$ & $8(0)$ & $6(0)$ \\
\hline Но & 0.320 & 0.320 & 0.280 & 0.360 & 0.340 & 0.300 \\
\hline $\mathrm{He}$ & 0.373 & 0.323 & 0.381 & 0.393 & 0.310 & 0.275 \\
\hline Fis (W\&C) & 0.143 & 0.011 & 0.092 & 0.085 & -0.099 & -0.093 \\
\hline \multicolumn{7}{|c|}{ Mean acrossloci $\pm S D$} \\
\hline$\overline{A(A p)}$ & $7.1 \pm 3.3$ & $7.2 \pm 3.4$ & $6.9 \pm 2.5$ & $7.0 \pm 3.2$ & $7.0 \pm 2.9$ & $6.9 \pm 3.1$ \\
\hline Ho & $0.386 \pm 0.117$ & $0.378 \pm 0.167$ & $0.426 \pm 0.123$ & $0.369 \pm 0.154$ & $0.413 \pm 0.167$ & $0.398 \pm 0.159$ \\
\hline $\mathrm{He}$ & $0.662 \pm 0.141$ & $0.657 \pm 0.167$ & $0.639 \pm 0.170$ & $0.647 \pm 0.170$ & $0.620 \pm 0.200$ & $0.661 \pm 0.175$ \\
\hline Fis (W\&C) & $0.406 *$ & $0.410 *$ & $0.313 *$ & $0.426^{*}$ & $0.332 *$ & $0.369^{*}$ \\
\hline
\end{tabular}


